Божена МАРУНЕВИЧ, кандидат педагогічних наук, доиент кафедри німеиької філології ДВНЗ "Прикарпатський національний університет імені Василя Стефаника"

\title{
СПЕЦИФІКА НАВЧАННЯ НІМЕЦЬКОЇ МОВИ ЯК СПЕЦІАЛЬНОСТІ В УМОВАХ ШТУЧНОГО СУБОРДИНАТИВНОГО БІЛІНГВІЗМУ
}

\author{
Bozhena MARUNEVYCH, candidate of pedagogical sciences, as- \\ sociate professor of the German Philology Department, \\ Precarpathian National Vasyl Stefanyk University
}

\section{SPECIFIC FEATURES OF TEACHING GERMAN AS MAJOR IN THE ARTIFICIAL SUBORDINATE BILINGUALISM CONDITIONS}

\begin{abstract}
Стаття присвячена дослідженню проблеми навчання німецької мови як спеціальності в умовах міжмовної взаємодії рідної та іноземної мов. На основі детального аналізу психологічного аспекту штучного субординативного білінгвізму обгрунтовано доцільність урахування фактора двомовності як об'єктивної реальності в навчальному процесі; виділено психолінгвістичну концепцію взаємодії мовних кодів у свідомості білінгва як визначальну для розробки сучасної методики навчання німецької мови в умовах штучного білінгвізму.

Ключові слова: навчання німецької мови, штучний білінгвізм, психолінгвістичний підхід, функціонування психолінгвістичних механізмів
\end{abstract} білінгва.

Summary. The article investigates the problem of teaching German as major in the conditions of interlingual interaction of the native and the foreign languages. On the basis of a detailed analysis of the psychological aspect of artificial subordinate bilingualism, we have justified the relevance of the bilingualism factor as objective reality in the educational process; determined the psycholinguistic framework for the interaction of lingual codes in the bilingual person's consciousness as determinative for the development of modern methods of German language teaching in artificial bilingualism conditions.

Key words: teaching German, artificial bilingualism, psycholinguistic approach, functioning of

(C) Б. Маруневич psycholinguistic mechanism of a bilingual person.

Мета: охарактеризувати психологічний аспект штучного субординативного білінгвізму та обгрунтувати доцільність урахування фактору двомовності як об'єктивної реальності в навчальному процесі.

Постановка проблеми в загальному вигляді. Проблема навчання німецької мови як спеціальності та організації навчального процесу 3 урахуванням конкретних форм прояву білінгвізму належить до однієї 3 важливих та малодосліджених проблем сучасної методики навчання іноземних мов у вищій школі. У даний час білінгвальна освіта засобами вивчення рідної та іноземної мов $\epsilon$ важливою складовою частиною модернізації цілей і змісту національної освітньої системи України. Білінгвізм та мультилінгвізм стали характерними ознаками особистості, яка не може ефективно реалізувати свій потенціал без знання рідної та іноземної мов, особливо у професійній діяльності.

Специфічною особливістю навчання німецької мови як спеціальності $є$ той факт, що засвоєння іноземної мови в аудиторних умовах відбувається за відсутності природного мовного середовища та наявності у студентів-філологів сформованого на базі рідної мови мовленнєвого механізму. Тому цілком закономірно, що процес оволодіння мовленнєвою діяльністю на другій мові не може не накладатися на первинний, базовий код рідної мови $[1, c .5$; 12, c. $63 ; 14$, c. 47], а більш стійкі мовленнєві навички рідної мови виявля- ються домінуючими, що породжує відношення субординативної взаємодії мовних кодів у свідомості студента, у нашому випадку української та німецької мов.

Субординативний тип білінгвізму характеризується нерівноправним статусом: одна мова домінує, а інша займає підпорядковане положення, у ролі домінанти виступає рідна мова. На думку психолінгвіста Г. В. Колшанського, "рідна мова як первинний код повинна бути визнана базовою для встановлення відповідності 3 будь-яким вторинним мовним кодом як у процесі вивчення, так і у процесі володіння іноземною мовою [11,. 176]. За таких умов виникає необхідність організації навчального процесу з урахуванням конкретних форм прояву білінгвізму, оскільки тип білінгвізму є релевантним до процесу його формування.

Особливо значущою для нашого дослідження є проблема взаємодії мовних кодів у процесі мовленнєвомисленнєвої діяльності білінгва, розв'язання якої дає можливість розробки науково обгрунтованого підходу до навчання німецької мови в умовах штучного білінгвізму, а також дозволяє знайти підстави для використання таких методичних прийомів навчання, які відповідають закономірностям мисленнєвих процесів у період формування двомовності.

Аналіз досліджень і публікацій. Ураховуючи той факт, що двомовність (білінгвізм) є багатоплановою, багатоаспектною проблемою, яка однією своєю гранню безпосередньо стосується питання навчання мов, необхідно визначити, який підхід до тлумачення сутності 
білінгвізму визначальний для нашого дослідження.

Теоретичний аналіз робіт лінгвістів, психологів, психолінгвістів та методистів (М. Аствацатрян, У. Вайнрайх, Є. Верещагін, Л. Виготський, Ю. Жлуктенко, А. Карлінський, О. Коршук, О. Леонтьєв, М. Михайлов, 3. Муратова, Е. Хауген та ін.), у яких порушувалися питання двомовності, виявив два основні підходи, які $\epsilon$ визначальними для нашого дослідження: лінгвістичний та психолінгвістичний. Останній передбачає динамічний характер становлення двомовності, оскільки дозволяє враховувати функціонування психолінгвістичних механізмів білінгва на різних етапах його розвитку.

Систематична розробка класифікацій типів білінгвізму в психолінгвістичному та соціолінгвістичному аспектах належить У. Вайнрайху, де він протиставляє субординативний та координативний білінгвізм [4]. Типологія сучасного білінгвізму висвітлена у працях $Є$. Верещагіна, який виділяе типи білінгвізму на основі психолінгвістичних та методичних критеріїв: чистий і змішаний, безпосередній та опосередкований, природний і штучний, рецептивний, репродуктивний і продуктивний, координативний і субординативний (за характером взаємодії контактуючих мов у свідомості індивіда) [5].

Аналіз останніх публікацій свідчить, що українські науковці активно займаються питаннями двомовності. Детальному дослідженню різних підходів до проблеми двомовності присвячені роботи Н. Бурейко та А. Загнітко. Так, Н. Бурейко аналізує питання двомовності та методологічні основи психологічного дослідження білінгвів 3 позиції комплексного підходу [3, с. 22-29]. Значущим для нас $є$ виділення педагогічного аспекту, що грунтується на опрацюванні найраціональніших методів вивчення процесів оволодіння двомовністю [7, с. 213]. Психологічні основи продуктивного білінгвізму представлено в роботах Т. Пастрик та T. Боднарчук. Зокрема, вивченню психологічних засад перекладацької діяльності як специфічного виду мовленнєво-мисленнєвої діяльності білінгва стосується праця Т. Пастрик [15]. Продуктивною є ідея організації двомовного навчання як складової інтеграції українського соціуму у європейський [2, с. 71]. Т. Боднарчук вказує на те, що дослідження механізму переключення 3 однієї мови на іншу надзвичайно важливе для організації процесу навчання другої мови, тобто розвитку двомовного індивіда [2, с. 63-73]. Однак питання навчання німецької мови як спеціальності в умовах штучного субординативного білінгвізму висвітлені недостатньо і потребують грунтовного аналізу.

Виклад основного матеріалу дослідження. Виходячи 3 твердження, що метою будь-якого навчання нерідної мови $є$ формування білінгвізму того чи іншого типу [13, c. 25], а процес оволодіння іноземною мовою відбувається в умовах міжмовної взаємодії (української та німецької мов), вважаємо за доцільне розглядати фактор двомовності як об'єктивну реальність у навчальному процесі. Зауважимо, що з методичної точки зору нас цікавить не питання про двомовність у природних умовах спілкування, а процес іiі становлення в ході оволодіння іноземною мовою у штучних, тобто аудиторних умовах.

Природний білінгвізм має місце там, де вивчення другої мови відбувається внаслідок безпосереднього контактування 3 носіями мови у процесі спільної практичної діяльності; штучний білінгвізм виникає в ситуації цілеспрямованого вивчення другої мови у спеціально створених для цієї мети умовах, де мова вивчається опосередковано, через учителя, з використанням програм навчальних посібників і технічних засобів $[10$, с. 26$]$.

Наш інтерес до теорії двомовності пояснюється iï значущістю для практики викладання німецької мови як спеціальності у вищій школі. Методична цінність цієї теорії полягає в тому, що вона сприяє виявленню специфіки функціональної взаємодії мов у свідомості двомовця [10, с. 5]. Як зауважує Л. Виготський, "у випадку засвоєння іноземної мови пройдений шлях розвитку не повторюється", засвоєння іноземної мови здійснюється "через раніше засвоєну систему, яка стоїть між мовою і світом речей" [6, c. 265]. Такою системою є рідна мова, на якій базується іншомовна мовленнєва діяльність студента в умовах формування штучного білінгвізму. "Рідна мова як первинний код повинна бути визнана базовою для встановлення відповідності 3 будь-яким вторинним мовним кодом, як у процесі володіння, так і у процесі навчання іноземної мови $[11$, c. 176$]$.

У контексті теорії мовленнєвої діяльності І. Зимня та С. Толкачова виділяють три ступені в розвитку білінгвального стану: перший - формування і формулювання думки через посередництво рідної мови 3 наступним перекладом нерідною мовою (нижча ступінь); другий - формування думки засобами рідної мови $з$ наступним іiі формулюванням засобами нерідної мови (проміжний ступінь); третій - формування і формулювання думки відразу засобами нерідної мови (ступінь білінгвального стану) [9, с. 97].

На основі викладеного вважаємо правомірним стверджувати, що двомовність у штучних умовах проходитиме ряд стадій: від елементарного до повноцінного володіння іноземною мовою, тобто формування двомовності в аудиторних умовах слід розуміти як динамічний процес. Початковий етап оволодіння німецькою мовою характеризуватиметься як етап переходу від нижчої до проміжної стадії білінгвізму і відзначатиметься "взаємодією коду нової мовної системи 3 внутрішньомовленнєвим кодом студента, сформованим на базі рідної мови" [1, с. 67].

Залежно від цілей навчання можна формувати рецептивний, репродуктивний та продуктивний білінгвізм. За визначенням $€$. Верещагіна, рецептивний білінгвізм забезпечує розуміння іншомовного тексту, репродуктивний - розуміння та відтворення почутого і прочитаного, а продуктивний - розуміння, відтворення і породження іншомовного тексту [5, с. 25-29].

На цій підставі можна конкретизувати кінцеву мету навчання німецької мови як формування штучного продуктивного субординативного типу білінгвізму.

Вважливо зазначити, що співвідношення мовних систем у свідомості студента в умовах субординативного білінгвізму є складним з психофізіологічної точки зору, оскільки функціонування мовленнєвих механізмів залежить від закономірностей співвідношення рідної та іноземної мов і визначається стійкістю системи динамічних стереотипів, які перебудовуються у процесі навчання. Результати психофізіологічних і нейрофізіологічних досліджень підтверджують наш висновок про необхідність визнання взаємодії іншо- 
мовного мовленнєвого механізму, який формується, з механізмом, який уже сформований на базі рідної мови. Як вказує Т. Ушакова, цілісна система словесних структур, яка склалася при засвоєнні рідної мови, встановлює у своєму функціонуванні перебіг ряду процесів, пов'язаних із засвоєнням іноземної мови $[17$, c. $76-$ 77]. Доведено, що система словесних структур рідної мови служить подарунком у процесі оволодіння іноземною. Отже, розробка методики навчання німецької мови в умовах формування штучного білінгвізму повинна опиратися як на свою основу на виявлення особливостей взаємодії рідної та іноземної мов (української та німецької) у процесі мовленнєво-мисленнєвої діяльності білінгва. Неоднозначне, часто суперечливе вирішення проблеми взаємодії мовних кодів у методичному аспекті є однією з причин того, що сьогодні в методиці викладання не усунено протиріччя між необхідністю формувати новий самостійний стереотип і неминучістю використання у цьому рідної мови.

Доцільним для нашого дослідження є проведення аналізу мисленнєво-мовленнєвих процесів на основі гіпотетичних моделей породження висловлювання, представлених у науковій літературі (Л. Виготський, I. Зимня, О. Леонтьєв, А. Лурія, Т. Рябова-Ахутіна та ін.).

Вихідним положенням у проведенні такого аналізу є теза про те, що "мовленнєвий механізм, сформований на рідній мові, не функціонує на тому ж рівні в умовах оволодіння іншомовною мовленнєвою діяльністю; оволодіння новою діяльністю означає, що людина якось пристосовує, можливо, заново формує окремі ланки цього складного мовленнєвого механізму" [8, c. 168]. Виходячи 3 проведеного аналізу гіпотетичних моделей породження висловлювання, можна сказати, що всі автори єдині в тому, що процес породження висловлювання починається з вибору деякої загальної схеми, яка містить максимально сконцентрований смисл майбутнього висловлювання, або, за словами I. Зимньої, утворюється і розгортається загальний замисел, який формує смислову канву висловлювання [8, с. 169]. Перехід від замислу, або внутрішньої програми до її реалізації мовними засобами являє собою другий етап моделі, який, на переконання Л. Виготсько- го, є "словесним синтаксисом і граматикою слів" [6, с. 315].

Незважаючи на різне формулювання одного й того самого процесу, автори однаково тлумачать процес розгортання внутрішньої програми: він включає лексичне розгортання i граматичне структурування. У процесі лексичного розгортання здійснюється вибір слова за значенням у межах лексико-семантичної групи (вибирається те слово, яке відповідає смислу). Граматичне структурування передбачає синтаксичну реалізацію і морфологічне розгортання семантичних опорних лексичних одиниць, одержаних у процесі лексичного розгортання. Реалізація замислу лексичними і граматичними засобами конкретної мови здійснюється за допомогою мовленнєвих механізмів, які виступають складною динамічною системою. I. Зимня виділяє три плани функціонування мовленнєвого механізму: предметно-логічний, внутрішнього та зовнішнього оформлення [8, c. 171$]$. Саме механізми внутрішнього оформлення вважаються тими механізмами, які пристосовуються до умов оперування новими засобами і способами формування та формулювання думки.

Відповідно до завдань нашого дослідження обмежимо аналіз гіпотетичної моделі І. Зимньої формувальним рівнем, оскільки виділення даного рівня має методичне значення для визначення характеру впливу системи рідної мови та сформованих на їі основі механізмів лексико-граматичного розгортання висловлювання, тобто механізмів внутрішнього і зовнішнього оформлення іншомовного висловлювання.

Формувальний рівень названої моделі представлений двома фазами: смислоутворювальною та формулювальною. Саме цей рівень несе відповідальність за логічну послідовність та синтаксичну правильність мовленнєвого акту. На думку Т. Попової, саме тут підключається механізм внутрішнього перекладу, в основі якого лежать операції перекодування значень лексико-граматичних одиниць 3 рідної мови іноземною [16, $c$. 21]. Психологічна неминучість внутрішнього перекладу зумовлена тим, що студенти користуються у процесі іншомовного мовлення кодом внутрішнього програмування, сформованим на базі рідної мови.

Виділення у гіпотетичній моделі породження висловлювання додаткової ланки - етапу перекодування 3 рідної мови іноземною - дозволило інтерпретувати процес засвоєння іншомовного лексико-граматичного матеріалу як оволодіння психолінгвістичними операціями:

1) вибору згідно 3 комунікативним наміром;

2) перекодування з української мови німецькою мовою;

3) конструювання висловлювань німецькою мовою.

Висновки та перспективи подальших досліджень. Розуміння специфіки мисленнєвих процесів та взаємодії мовних кодів рідної (української) та іноземної (німецької) мов у свідомості студента забезпечує можливість психологічно обгрунтованого підходу до навчання німецької мови як спеціальності в умовах штучного субординативного продуктивного типу білінгвізму та використання у навчальному процесі методичних прийомів лінгвометодичного зіставлення, аналізу та перекладу, які відповідають закономірностям мовленнєво-мисленнєвих процесів у період формування двомовності. Проведений аналіз досліджень дозволяє виділити психолінгвістичну концепцію взаємодії мовних кодів як визначальну для розробки методики навчання німецької мови як спеціальності в умовах штучного субординативного продуктивного типу білінгвізму.

Перспективу подальших розвідок вбачаємо у розробці комплексної системи роботи з метою формування іншомовної компетенції з урахуванням взаємовпливу рідної та іноземної мов у період формування двомовності.

\section{ЛІТЕРАТУРА}

1. Аствацатрян М. Г. Обучение иностранному языку в условиях подвижного субординированного билингвизма (на примере немецкого языка в армянской школе) : дисс. ...дра пед. наук: 13.00.02. Москва, 1988. $370 \mathrm{c}$.

2. Боднарчук Т. В. Використання психолінгвістичних особливостей білінгвізму в процесі організації двомовного навчання. Вісник Львів. унту. Львів, 2008. Вип. 23. С. 63-73.

3. Бурейко Н. О. Методологічні засади психологічного дослідження білінгвів у наукових підходах до психолінгвістичної типології білінгвізму. 
Вісник Харків. нац. пед. ун-ту ім. Г. С. Сковороди. Харків, 2014. Вип. 48. C. 22-29.

4. Вайнрайх У. Языковые контакты. Состояние и проблемы исследования / перевод с англ. и коммент. Ю. А. Жлуктенко. Київ: Вища школа, $1979.264 \mathrm{c}$.

5. Верещагин Е. М. Психологическая и методическая характеристика двуязычия. Москва : Изд-во Моск. унта, 1969.160 с.

6. Выготский Л. С. Проблемы общей психологии : у 2 т. / под. ред. В. В. Давыдова. Москва : Педагогика, 1982. Т. $2.504 \mathrm{c}$.

7. Загнітко А. П. Кваліфікаційні та класифікаційні ознаки білінгвізму: аспекти, різновиди, методи. Лінгвістичні студії. 2013. Вип. 26. С. 209-219.

8. Зимняя И. А Психология обучения неродному языку. Москва : Русский язык, 1989. 219 с.

9. Зимняя И. А., Толкачева С. Д. Сопоставительный анализ текста на русском и иностранном языках как прием повышения уровня владения иностранным языком. Психология билингвизма: сб. науч. труд. Москва : Моск. гос. пед. ин-т иностр. яз., 1986. Вып. 260. С. 95-103.

10. Карлинский А. Е. Основы теории взаимодействие языков и проблемы интерференции: дисс. ...докт. филол. наук: 10.02.04. Алма-Ата, 1980. $311 \mathrm{c}$.

11. Колшанский Г. В. Теоретические проблемы билингвизма. Лингвистика и методика в высшей школе. Москва, 1967. Вып. 4. С. 174-176.

12. Лапидус Б. А. Некоторые теоретические вопросы методики обучения иностранных языков: хрестоматия / сост. А. А. Леонтьев. Москва : Русский язык, 1991. С. 61-69.

13. Леонтьев А. А. Психолингвистические и социолингвистические проблемы билингвизма в свете методики обучения неродному язику. Психология билингвизма: сб. науч. труд. Москва : Моск. гос. пед. ин-т иностр. яз., 1986. Вып. 260. С. 25-31.

14. Миньяр-Белоручев Р. К. О принципах обучения иностранным языкам. Общая методика обучения иностанным языкам: хрестоматия / сост. А. А. Леонтьев. Москва : Русский язык, 1991. С. 43-53.

15. Пастрик Т. В. Психологічні особливості формування продуктивного білінгвізму у майбутніх перекладачів: дис. ...канд. психол. наук: 19.00.07. Острог, 2007. 187c.

16. Попова Т. В. Обучение связному высказыванию в процессе иноязычного порождения на начальном этапе овладения испанским язиком (I курс языкового вуза): дис. ...канд. пед. наук: 13.00.02. Минск, 1990.187 c.

17. Ушакова Т. Н., Павлова Н. Д., Зачесова И. А. Речь человека в общении. Москва : Наука, 1989. 192 с.

\section{REFERENCES}

1. Astvatsatrian M. H. Obuchenye inostrannomu yazyku v uslovyiakh podvizhnoho subordinirovannoho bilinhvizma (na primere nemetskoho yazyka $\mathrm{v}$ armianskoi shkole): dis. ...dokt. ped. nauk: 13.00.02. Moskva, $1988.370 \mathrm{~s}$.

2. Bodnarchuk T. V. Vykorystannia psykholinhvistychnykh osoblyvostei bilinhvizmu v protsesi orhanizatsii dvomovnoho navchannia. Visnyk Lviv. un-tu. 2008. Vyp. 23. S. 63-73.

3. Bureiko N. O. Metodolohichni zasady psykholohichnoho doslidzhennia bilinhviv u naukovykh pidkhodakh do psykholinhvistychnoi typolohii bilinhvizmu. Visnyk Kharkiv. nats. ped. un-tu im. H. S. Skovorody. Psykholohiia. 2014. Vyp. 48. S. 22-29.

4. Vaynraykh U. Yazykovye kontakty. Sostoyaniye i problemy issledovanyia / Perevod s anhl.. i kommentarii Yu. A. Zhluktenko. Kyiv : Vyshcha shkola, 1979. 264 s.

5. Vereshchagin E. M. Psikhologicheskaya i metodicheskaia kharakteristika dvuyazychyia. Moskva : Izd-vo Mosk. un-ta, 1969. 160 s.

6. Vygotskyi L. S. Problemy obshchey psikholohii: v 2 t. / pod. red. V. V. Davydova. Moskva : Pedahohika, 1982. T. 2. $504 \mathrm{~s}$.

7. Zahnitko A. P. Kvalifikatsiini ta klasyfikatsiini oznaky bilinhvizmu: Aspekty, riznovydy, metody. Linhvistychni studii. 2013. Vyp. 26. S. 209-219.

8. Zimnyaya I. A Psikhologiya obucheniya nerodnomu yazyku. Moskva : Rus.yaz.. 1989. 219 s.

9. Zimnyaya I. A.. Tolkacheva S.D. Sopostavitelnyy analiz teksta na russkom i inostrannom yazykakh kak priyem povysheniya urovnya vladeniya inostrannym yazykom. Psikhologiya bilingvizma: Sb. nauch. tr. Moskva : Mosk. gos. ped. in-t inostr. yaz.. 1986. Vyp. 260. S. 95-103.

10. Karlinskiy A. E. Osnovy teorii vzaimodeystviye yazykov i problemy interferentsii: dis. ...dokt. filol. nauk: 10.02.04. Alma-Ata. 1980. $311 \mathrm{~s}$.

11. Kolshanskiy G. V. Teoreticheskiye problemy bilingvizma. Lingvistika i metodika v vysshey shkole. Moskva, 1967. Vyp. 4. S. 174176.

12. Lapidus B. A. Nekotorye teoreticheskiye voprosy metodiki obucheniya inostrannykh yazykov: khrestomatiya / sost. A. A. Leontev. Moskva : Rus. yaz.. 1991. S. 61-69.

13. Leontev A. A. Psikholingvisticheskiye i sotsiolingvisticheskiye problemy bilingvizma $\mathrm{v}$ svete metodiki obucheniya nerodnomu yaziku. Psikhologiya bilingvizma: Sb. nauch. tr. Moskva: Mosk. gos. ped. in-t inostr. yaz.. 1986. Vyp. 260. S. 25-31.

14. Miniar-Beloruchev R. K. O printsipakh obucheniya inostrannym yazykam. Obshchaya metodika obucheniya inostannim yazykam: khrestomatiya / sost. A. A. Leontev. Moskva: Rus. yaz. 1991. S. 43-53.

15. Pastryk T.V. Psykholohichni osoblyvosti formuvannia produktyvnoho bilinhvizmu u maibutnikh perekladachiv: dys. ...kand. psykhol. nauk: 19.00.07. Ostroh, 2007. $187 \mathrm{~s}$.

16. Popova T.V. Obucheniye svyaznomu vyskazyvaniyu $\mathrm{v}$ protsesse inoyazychnogo porozhdeniya na nachalnom etape ovladeniya ispanskim yazikom (I kurs yazykovogo vuza): dis. ... kand. ped. nauk: 13.00.02. Minsk. 1990. $187 \mathrm{~s}$.

17. Ushakova T. N. Pavlova N. D. Zachesova I. A. Rech cheloveka V obshchenii. Moskva: Nauka. 1989. 192 s.

Стаття надійшла 24.04.2019 р. 